\title{
Pemanafaatan aplikasi Geogebra sebagai pembelajaran Matematika di SMA kabupaten Buru
}

\author{
Irma Magfirah ${ }^{1^{\star}}$, Yusran Zakaria ${ }^{2}$, Risman lye $^{3}$, Riki Bugiz $^{4}$, Azwan $^{5}$ \\ 1,2,3Fakultas Keguruan dan IImu Pendidikan, Universitas Iqra Buru, Indonesia \\ ${ }^{4,5}$ Fakultas Sastra, Universitas Iqra Buru \\ *Korespondensi: azharpolitik@gmail.com
}

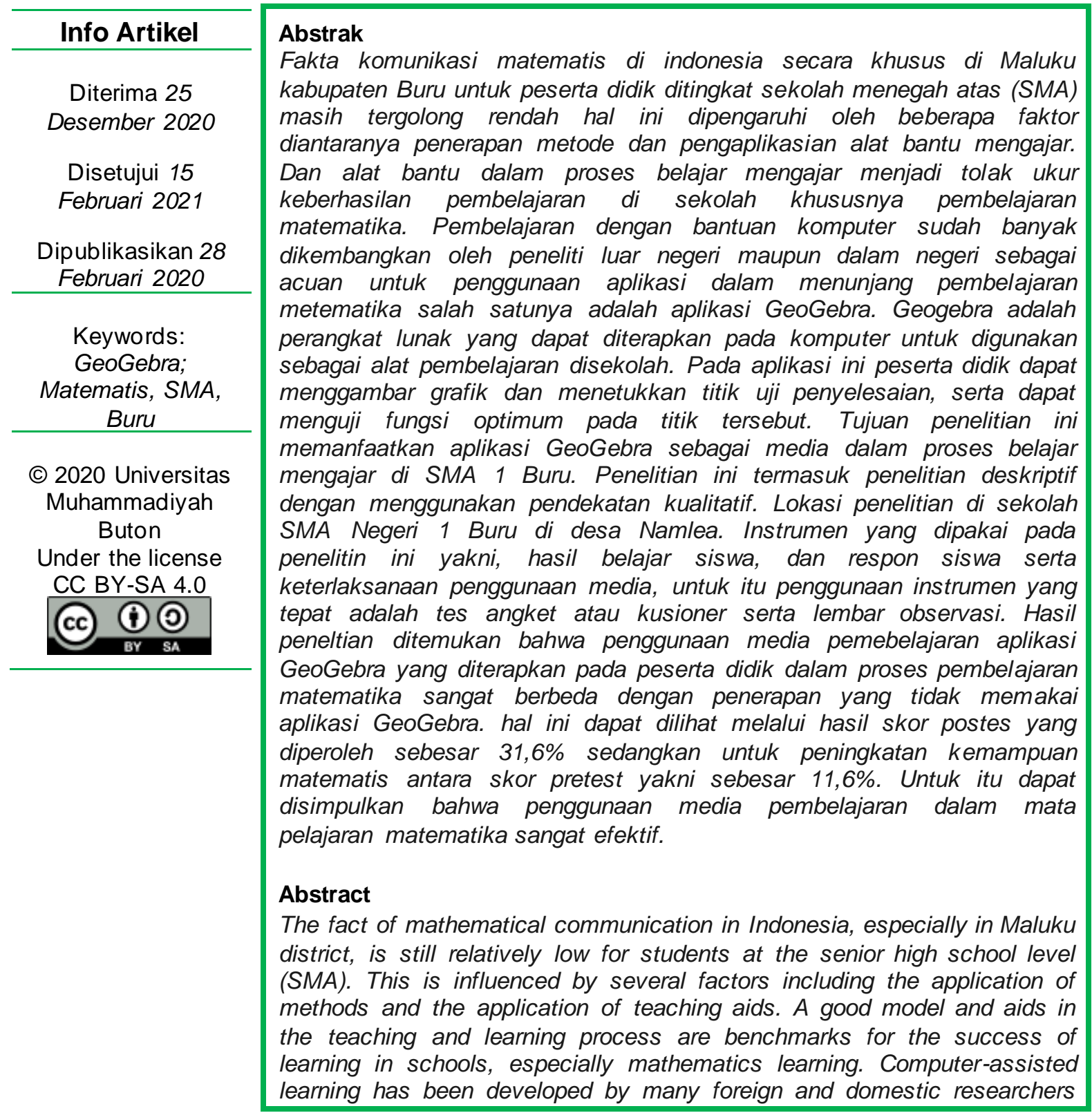


as a reference for the use of applications to support learning mathematics, one of which is the GeoGebra application. Geogebra is software that can be applied to computers to be used as a learning tool in schools. In this application students can draw graphs and determine the test point of completion, and can test the optimum function at that point. The. purpose of this study is to utilize the GeoGebra application as a medium in the teaching and learning process at SMA 1 Buru. This research is a descriptive study using a qualitative approach. The research location is the Buru 1 Public High School in the village of Namlea. The instruments used in this research are student learning outcomes, student responses as well as the feasibility of using the media for that use of appropriate instruments is a questionnaire test or questionnaire and observation sheets. The results of the study found that the use of the GeoGebra application learning media which is applied to students in the mathematics learning process is very different from the application that is not sufficient in the GeoGebra application. This can be seen through the results of the posttest score obtained by $31.6 \%$, while the increase in mathematical ability between the pretest scores is $11.6 \%$. For this reason, it can be concluded that the use of learning media in mathematics is very effective.

\section{Pendahuluan}

Pembelajaran Matematika di sekolah kadang membuat siswa-siswi mengalami kesulitan dalam menerima materi dari guru, terutama dalam menangkap dan menunggkapkan gagasan matematis. Salah satu faktor dan penyebabnya adalah siswa dalam memahami pelajaran belum sesuai dengan apa yang diharapkan atau konsep matematis tidak dipahami secara menyeluruh Pembelajaran matematika di Indonesia saat ini masih menitiberatkan pada pembelajaran secara langsung yaitu seorang pendidik menyampaikan secara langsung materi yang dibawakan kepada peserta didik yang kesemuanya gu rulah yang dominan dalam peoses pembelajaran. Sehingga penerapan pemebelajaran ini siswa berinteraksi pasif menerima proses pembelajaran tersebut. Proses pembelajaran yang didominasi oleh guru tersebut merupakan pembelajaran satu arah (Tarmudi, 2011). Keadaan pembelajaran satu arah tersebut siswa kurang mendapatkan kesempatan untuk berpartisispasi dalam proses pembelajaran dalam ruangan.

Salah satu tujuan pembelajaran matematika di Indonesia harusnya disesuikan dengan standar Isi (Permendiknas No. 22 tahun 2006) yakni pembelejaran matematika dikomunikasikan dengan simbol, tabel, diagram, atau media lain untuk membantu dan memperjelas keadaan atau masalah yang dihadapi. Namun pada prosesnya pembelajaran matematika hanya pada tataran meberikan materi dan tugas seperti pembelajaran lainya. Hal ini seperti ditemukan pada penelitian yang dilakukan oleh (Roehati, 2009). Dengan menemukan bahwa rerata kominikasi matematis siswa atau peserta didik di Inonesia masing belum dikatakan baik. Sejalan dengan peneitian tersebut the international mathematics and scince study (Martin, M. O., Mullis, I. V., \& Foy, 2008) Mengungkapkan bahwa di Indonesia pembelajaran matematika masih berada pada level 36 dari 48 negara yang telah disurvei pada komunikasi matematisnya.

Komunikasi dapat diartikan sebagai penyampaian gagasan atau ide sehingga dapat dilaukuakn dan diklarifikasi oleh pendengar. (lye, 2020) Melalui komunikasi 
seseorang atau pembicara mentransfer ide dan menjadi objek-objek refleksi dan dapat didiskusikan (NCTM, 2000). Komunikasi matematis adalah kemampuan untuk menyatakan ide secara tulisan maupun lisan dan dapat mencapai indikator yang ditentukan oleh si Komunikator. Berdasarkan indikator komunikasi matematis yang dikembangkan (NCTM, 2000) Utari Sumarsono dalam (Sulastri, 2009). Pada penelitian tersebut indikator yang dikembangkan yakni a) menyatakan peristiwah sehari-hari dalam bahasa symbol matematis; b) mengungkapkan ide metematis dengan menggunakan gambar, tabel atau penyampaian secara aljabar; c) menuliskan gagasan matematis yang akan disajikan berbentuk gambar dan tabel.; dan; d) mmeberikan solusi terhadap pemebeljaran melalaui gambar, tabel dan aljabar.

Tujuan pengembangan komunikasi matematis pada dasarnya agar siswa dapat lebih memahami pemebelajaran matematika dan memeknainya tidak hanya pada tataran simbol tanpa makna melainkan harus memiliki makna. Penyampaian melalui lambang juga dapat menjadi bahasa yang berguna untuk membantu tingkat pemahaman siswa dalam menyelesaikan masalah pembelajaran matematis baik disekolah maupun dikehidupan sehari-hari (Susiati, S., lye, R., 2019). Sehubungan dengan hal tersebut. Pendidik di sekolah sangat berperan penting dalam proses belajar mengajar di sekolah agar peserta didik dapat memehami pembelajaran yang disampaikan secara khusus pembelajaran matematika. Untuk itu diperlukan metode, ataupun model pembelajaran serta pendekatan yang akan diterapkan kepada peserta didik. Pendekatan yang harus diterpakan adalah pendekatan matematika realistic. Pendekatan matematika realistic telah suskses diterapkan di belanda pada tahun 1973. Tokoh pertama yang mengenalkan pendekatan matematika relaistik adalah Freudental. la mengatakan bahwa' mathematics is a human activity' artinya matematika adalah aktivitas manusia (Zulkardi, 2002). Oleh karena itu pembelajaran matematika tidak bisa dipisahkan dengan kehidupan sehari-hari. Ada lima prinsip uatama dalam pemebelajaran matematika realistic yang diungkapkan oleh (Tarmudi. 201yakni, Fokus pada masalah situasional sebagai sumber dan menerapkan konsep matematika; 2) Memperhatikan perkembangan model, situasi, skema dan simbol; 3) Menghasilkan dan berkontribusi, artinya siswa membangun algoritma dan aturannya sendiri sehingga guru dapat Hanya siswa tingkat matematika informal yang men garah ke siswa tingkat matematika formal; 4) Interaktivitas adalah karakteristik dari proses pembelajaran matematika; 5) Jalinan (duplikasi) antara atau antar topik.

Pada pendekatan realistic salah satu filosofi yang mendasarinya yakni matematika bukanlah satu kumpulan atauran yang bersifat lengkap dan sempu rna melainkan sebagai pembelajaran yang dinamis dan dapat dipelajari dengan cara mengerjakan pada proses penyelsain pemrmasalahan tau biasa disebut dengan matematisasi. Terkait dengan aktifitas matematisasi dalam proses pembelajaran matematika Van den Heuvel-Phuizen, 1998. Mengatakan bahwa ada dua jenis matematisasi yakni matematisasi horizontal dan matematisasi fertikal. Matematisasi Horizontal berkaitan dengan proses transformasi masalah pada kehidupan sehari-hari yang diapresiasikan kedalam bentuk simbol sedangkan matematisasi vertikal yakni proses yang terjadi pada lingkup matematis itu sendiri.

Berbagai negara telah melakukan berbagai penelitian pembelajaran matematika dengan menerapkan pendekatan realistik yang dapat mengemas pembelejaran matematis lebih menarik, bermakna sehingga disukai oleh peserta 
didik. Namun di indonesia penerpan pembelajaran matematika di indonesia terkadang membutuhkan waktu yang lama untuk dapat menemukan konsep agar siswa dapat memehami dan menyelesaikan pembelajaran. Seiring perkembangan waktu di era globalisasi atau generasi 4.0 perkembangan teknologi begitu pesat di dunia begitu juga di Indonesia, melalui pengembangan tersebut teknologi dapat dijadikan sebagai alat bantu untuk digunakan oleh pendidik/guru dalam memberikan pembelajaran di sekolah. Teknologi ini dapat digunakan sebagai media khususnya komputer dijadikan sebagai media pembelajaran untuk dapat mentransfer ilmu pengetahuan utamanya pembelajaran matematika kepada siswa. Splittgerber dan Stirzake dalam (Aw, 2011) mengungkapkan bahwa waktu proses pembelajaran yang efektif disampaikan melalui media yang dijadikan sebagai alat bantu dalam proses belajar mengajar. Komputer memiliki banyak software yang digunakan untuk membantu proses belajar khususnya pembelajaran matematika. Salah satu software yang dapat diakses melalui komputer yang dapat dijadikan sebagai media pembelajaran adalah yaitu GeoGebra. GeoGebra dikembangkan pertama kali oleh Markus Hohenwarter, pada tahu 2008. Menurut (Hohenwarter, M. \& Fuchs, 2004) GeoGebra adalah program komputer yang yang digunakan pada pembelajaran matematika khsusunya geometri dan aljabar. GeoGebra juga meruapakan software open- source yang dapat diunduh oleh guru maupun siswa yang dapat digunakan sebagai alat bantu perhitungan aljabar dan geometri. Aplikasi juga ini diperoleh secara gratis di https//www.geogebra.com. Program ini juga memiliki spesifik bahasa yang multilingual dan dapat diakses dengan bahasa Indonesia.

GeoGebra memungkinkan untuk dipergunakan dengan mudah oleh siswa dan mampu aktif agar dalam pengenalan geometri dan aljabar. Program GeoGebra peserta didik akan mampu merancang visualisasi dari aplikasi tersebut hingga dapat memberikan keleluasaan siswa dalam menerapakan ide dan gagasan matematisnya yang akan ditepakan melalui GeoGebra. Hal ini didukung pula oleh (Hohenwarter, M. \& Fuchs, 2004) menyatakan bahwa GeoGebra memeiliki manfaat yang penting diantaranya; 1) dapat digunakan sebgai media dan visualisasi; b) dapat digunakan sebagai alat bantu komuikasai; c) sebagai alat bantu proses pebnemuan dan; d) sebagai alat komunikasi dan representasi.

Melalui latar belakang di atas maka tujuan penelitian ini yaitu bagaimana pemanfaatan aplikasi Geogebra dalam pembelajaran matematika yang diterapakan pada siswa SMA Negeri 1 Buru.

\section{Metode}

Penelitian ini bertujuan untuk mengetahui pemenfaatan aplikasi GeoGebra pada siswa SMA 1 Namlea serta hasil belajar serta respon siswa terhadap aplikasi GeoGebra mengetahui hasil penggunaaan media GeoGebra selanjutnya peneliti menyimpulkan apakah penggunaaan aplikasi GeoGebra dapat digunakan sebagai alat pembelajaran matematika selanjutnya. Penelitian ini merupakan

Penelitian ini merupakan penelitian mix Methods yakni menggabungkan dua penelitian sekaligus yaitu kulitatif dan kuantitatif. Model mix methods yang digunakan pada penelitian ini yaitu model sequential dengan menggunakan pendekatan explanatory, yaitu data dan analisis kuantitatif pada tahap pertama, dan diikuti pengumpulan dan analisis data kualitatif pada tahap ke dua guna memperkuat hasil penelitian kuantitatif yang dilakukan pada tahap pertama 
(Sugiyono, 2011). Lokasi penelitian yakni di Kabupaten Buru tepatnya di SMA Neg, 1 Namlea. Yang difokuskan pada siswa kelas X tahun ajaran 2019/2020. Selanjutnya subjek penelitian ini yaitu siswa kelas X SMA Neg. 1 Namlea dengan jumlah 20 orang yang terbagi atas 11 siswa laki-laki dan 9 siswa perempuan.

Waktu penelitian selama 7 Bulan dan pertemuan tatap muka berjumlah 7 kali materi yang diajarkan adalah sifat-sifat bangun datar yaitu pada pertemuan pertama penulis menjelaskan sifat-sifat bujur sangkar (segi empat) dan diakhir pembelajaran siswa/ peserta didik diberikan tes mengenai materi yang sudah diajarkan. Kemudian pada pertemuan kedua penulis merefleksi hasil pertemuan pertama dengan siswa-siswi dan setelah selesai merefleksi dilanjutkan dengan materi selanjutnya yakni mengenalkan sifat-sifat belah ketupat, layang-layang dan jajargenjang. Pada pertemuan selanjutnya dilanjutkan dengan menyajikan kepada peserta didik tes angket. Instrument yang digunakan dalam penelitian ini yaitu hasil belajar siswa, respon siswa, dan keterlaksaaan penggunaan media sehingga instrument yang tepat dalam mengukur adalah tes angket atau kuisioner serta lembar observasi.

\section{Pembahasan}

Hasil penelitian ditemukan bahwa penggunaan aplikasi GeoGebra yang diterapkan kepada siswa/siswi SMA Negeri 1 Buru pada pembelajaran matematika berbeda secara signifikan dengan siswa yang memperoleh pembelajaran tanpa bantuan aplikasi GeoGebra. Penerapan aplikasi Geogebra yang digunakan penulis pada proses pembelajaran memberikan pengaruh sebesar 31,6\% terhadap skor protest. Sedangkan peningkatan kemampuan komunikasi matematis Antara skor prets dan postest yakni sebesar $11,6 \%$. Kemampuan matematis yang diterapkan melalui aplikasi GeoGebra lebih baik dan efektif dibandingkan dengan tidak melalui Aplikasi GeoGebra ini didukung oleh hasil rata-rata $76,74 \%$ dari skor protes eksperimen 1 dan $74,37 \%$ dari rata-rata skor post-tes eksperimen 2 .

Sedangkan Berdasarkan hasil analisis tabel observasi guru dan siswa dapat diketahui bahwa sesuai dengan rencana pembelajaran yang dibuat oleh guru, pembelajaran di sekolah tersebut berjalan dengan baik. di sekolah dan penerapanya membuat siswa lebih aktif dan merespon pembelajaran matematika di kelas. Siswa/siswi merasa senang dengan pembelajaran yang diterpakan. Hal ini dipengaruhi oleh aplikasi GeoGebra yang memudahkan siswa dalam mengerjakan dan mengetahui apliasi tersebut. Wawasan siswapun bertambah kerena merelka dapat memeperoleh hal baru tentang pengoperasian aplikasi GeoGebra. Walaupun hal tersebut meruapakan penerapan pembelajaran yang baru dalam menagplikasikan aplikasi namun mereka tidak mengalami kesulitan menggunakan aplikasi mereka justru merasa bangga ketika bereksplorasi dengan GeoGebra.

Hasil angket respon juga menunjukkan bahwa siswa secara umum menunjukkan respon yang positif mengenai kesengangan mereka terhadap pembelajaran matematika relistik dengan bantuan GeoGebra. Hal ini membuat peserta didik termotivasi belajar matematika. Peserta didik juga merasakan manfaat dari pembelajaran atematika yang diterapkan. Pembelajaran matematika melalui aplikasi GeoGebra Juga meningkatkan kemampuan peserta didik untuk berpikir kreatif dan self-cocept sebagaimana ditunjjukan juga pada penelitian (Rahman, 2011). Tetapi juga mamapu meningkatkan kemampuan komunikasi 
matematis peserta didik. Sementara itu melalui hasi penelitian (Wulanratmini, 2011) mengungkapkan bahwa Geogebra juga tidak hanya pada tataran meningkatkan kemamupan siswa dalam pemebeljaran matematika melainkan meningkatkan penefdekatan pemebelajaran matematika relistik serta dapat menumbuhkan kreatifitas peserta didik untuk berksprimen melalui aplikasi GeoGebra.

Permasalahan yang terjadi akan diterangkan oleh guru kepada peserta didik untuk dijadikan bahan diskusi pada saat proses belajar mengajar berlangsung agar siswa dapat menemukan konsep matematis yang baik dan formal. Seperti halnya penelitian (Hohenwarter, M. \& Fuchs, 2004). GeoGebra dapat dimanfaatkan sebagai media untuk mendesain model matematis sehingga peserta didik dapat menemukan konsep matematis dan GeoGebrapun dapat digunakan sebagai alat komuniakasi dan representasi. Siswa melakukan diskusi secara berkolompok diruang kelas untuk menyelesaikan masalah matematis yang dihadapi (Prabawanto, 2013). Peserta didik dapat berinteraksi menggunakan komunikasi sebagi bagian dari proses belajar mengajar dan membangun pengetahuan dari gagasan matematis yang didapatkan di sekolah. Dengan diskusi juga peserta didik dapat berinterksi dengan siswa lain ataupun teman dilingkunganya. Peningkatan kemampuan komunikasi matematis juga terjadi kepada siswa yang memeperoleh pembeljaran matematika tanpa bantuan aplikasi GeoGebra walaupun kulitas peningkatanya tidak sama dengan pembelajaran matemtis melalui bantuan aplikasi GeoGebra. Dengan demikian pembelajaran matematika realistic tidak hanya dapat meningkatkan kemampuan komunikasi melainkan peningkatan kretifitas siswa juga. konsep yang telah diungkapkan di atas ditegaskan pula oleh (Sulastri, 2009) mereka dalam penelitianya menemukan bahwa matematika relistik yang diterapkan kepada siswa mampu meningkatkan komunikasi matematisnya.

Splittgerber dan Stirzaker (dalam Sunarto, 2011 mengemukakan bahwa jika strategi pembelajaran menggunakan pembelajaran komputer maka waktu pembelajaran akan lebih efektif. Dalton yang dikutip (Aw, 2011) menungkapkan bahwa proses pembeljaran yang memakai alat misalnya komputer dalam menyampaikan meteri akan menghemat waktu pemebeljaran. Sehingga ia juga menekankan bahwa proses pmeblejaran matematika realistik bukanlah pengetahuan yang diberikan kepada pesert didik secara instan melainkan membutuhkan proses dan metode yang baik agar siswa mampu memahami kontek pemebeljaran yang diterapkan terlebih penerapan alat mengajar seperti Komputer. Kemudian pada proses pembelajaran juga seorang pendidik harus mampu memeberikan waktu yang luang kepada siswa untuk merespon dan ikut aktif dalam pembelajaran.

Oleh sebab itu penerapan pembelajaran baik dan benar yakni ketika siswa ikut aktif dan mereka dijadikan sebagai pusat proses pembelajaran dan pendidik harusnya hanya menjadi fasiltator kepada peserta didik. Instruksikan siswa untuk membangun pengetahuan sendiri. Untuk mencapai situasi dan kondisi pembelajaran tersebut, dalam pembelajaran manajemen, guru perlu mendorong siswa untuk berani mencoba berbagai cara yang mungkin untuk memahami dan memecahkan masalah. Dibandingkan dengan penggunaan GeoGebra, hal ini membuat siswa menghabiskan waktu lebih lama untuk menyelesaikan masalah, dan cara siswa dalam memecahkan masalah menjadi terbatas. 
Dari sudut pandang di atas, dapat disimpulkan bahwa keberadaan proses pengaplikasin GeoGebra terhadap peserta didik menjadi tolak ukur keberhasilan penelitian ini yaitu apakah siswa mampu meningkatkan komunikasi matematisn ya melalui penerapan aplikasi ini serta bagimana perbandingan antara siswa yang diajarkan dengan bantuan aplikasi GeoGebra dan siswa yang tidak diperban tukan dengan aplikasi. Maka hasil yang didapatkan oleh peneliti yakni belajar melalui aplikasi GeoGebra memiliki perbedaan yang signifikan. Pembelajaran matematika realistik dapat dilakukan tanpa bantuan GeoGebra namun untuk untuk mencapai hasil yang maksimal akan kurang dipahami tanpa penerapan aplikasi.

Hasil yang didapatkan juga terbukti bahwa proses pembelajaran matematika realistik yang dilakukan dengan bantuan aplikasi GeoGebra peserta didik merespon dengan baik. Hal ini sesuai dengan penelitian yang dilakukan oleh (Abd. Rahman, 2011) siswa yang menggunakan aplikasi GeoGebra untuk pembelajaran mendapatkan respon yang positif. Siswa dapat merespon secara positif, karena dengan GeoGebra, siswa dapat mengeksplorasi banyak hal yang tidak mereka ketahui sebelumnya. (Alan Ralph, Hogan,S.J., Hill. M., 1998), menunjukkan bahwa GeoGebra memungkinkan siswa untuk secara bebas dan aktif mengeksplorasi objek dan konsep matematika. Siswa juga menganggap GeoGebra sangat membantu untuk memecahkan masalah matematika. Untuk menyelesaikan masalah matematika, lebih tepat menggunakan komputer daripada kertas dan pensil dalam beberapa aspek (Hares Uki, 2020)

Walaupun GeoGebra merupakan hal baru dalam pembelajaran matematika, siswa tidak merasa kesulitan untuk menggunakannya. Hal ini dikarenakan software GeoGebra sendiri didesain agar mudah digunakan dan tidak membutuhkan banyak penjelasan dan penjelasan (Preiner, 2008). Selain itu, terdapat masalah situasional sebagai titik awal pembelajaran, kemu dian digunakan GeoGebra untuk menemukan konsep matematika sehingga siswa dapat menikmati pembelajaran dengan cara tersebut. Masalah situasional memainkan peran penting dalam pembelajaran karena dapat memungkinkan siswa untuk lebih memahami pentingnya pembelajaran konsep matematika (Zulkardi, 2002) Saat menghadapi masalah situasional, siswa akan lebih termotivasi untuk belajar yakni, rasa sengang,

Dengan penjelasan di atas serta perbandingan dengan hasil penelitian yang didapatkan oleh peneliti bahwa respon positif peserta didik terhadap penerapan GeoGebra yakni peserta didik merasa senang, serta meningkatkan motivasi belajar yang lebih baik. hal Ini termasuk dalam posisi keberhasilan pembelajaran matematika dan merupakan aspekyang dapat memotivasi siswa (Zulkardi, 2002). 


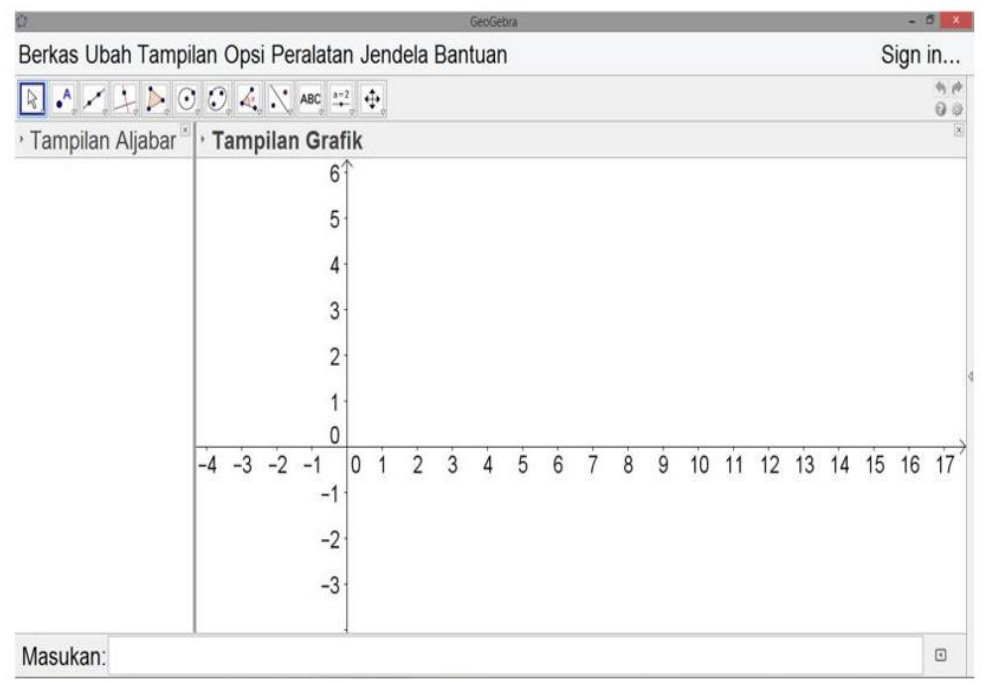

Gambar 1. Tampilan aplikasi GeoGebra

Pada Tampilan gambar tersebut merupakan tampilan depan aplikasi GeoGebra yang sangat sederhana yang terdiri atas, a) pada menu ini terdiri atas berkas, ubah, tampilan, opsi, jendela, peralatan, dan bantuan;b) tool bar, berisikan item-item, dan symbol; c) jendela kiri, berisikan tempat ditampilkanya bentukbentuk aljabar; d) jendela kanan terdiri atas tempat ditampilkan grafik; e) masukan yang terletak di di bagian kiri bawah, dan f) simbol, berisikan simbol.

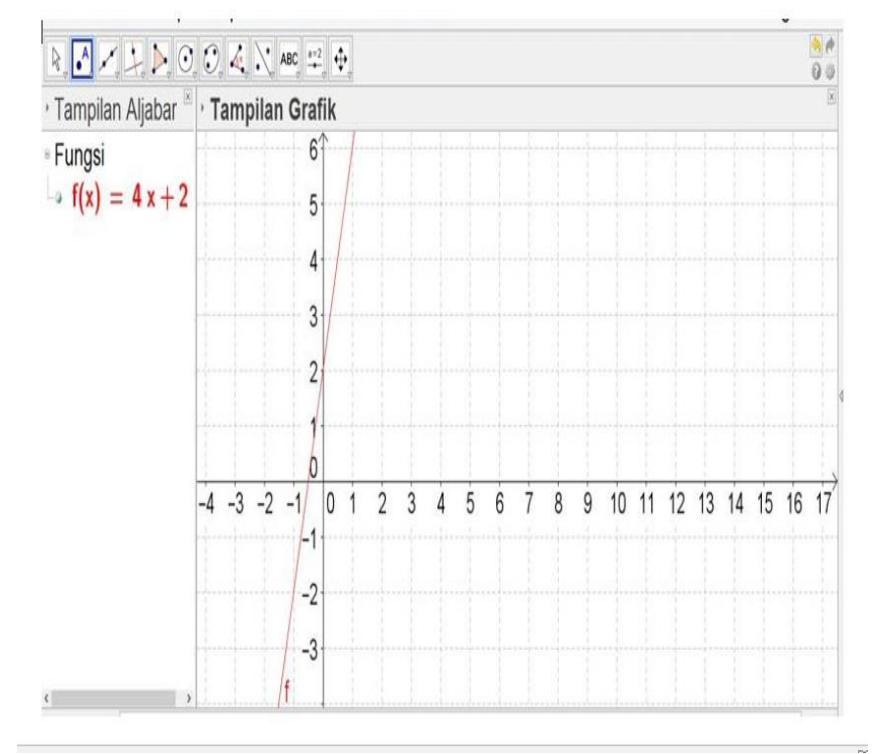

Gambar 2. Grafik dan Fungsi Linear

Gambar di atas adalah fungsi linier. Produk dari fungsi linier adalah pangkat atau grafik dari suatu fungsi adalah garis lurus. Oleh karena itu, fungsi linier biasanya disebut persamaan linier, dan bentuk umumnya adalah $f(x)=a x+b$. Perintah untuk menggambar grafik fungsi linier ada di kolom masukan tipe $f(x)=$ $4 x+2$, lalu grafik hasil. 


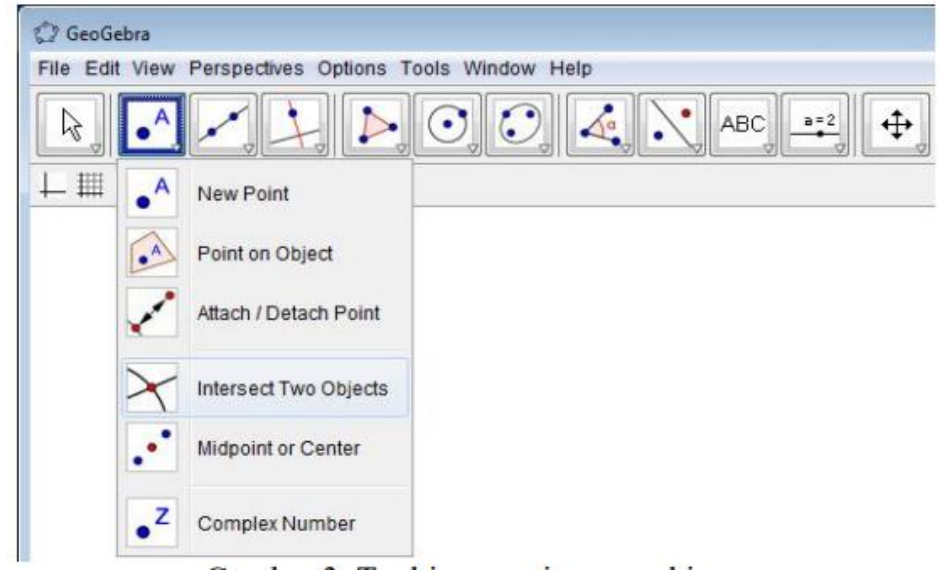

Gambar 3. Tool intersection two objects

Gambar 3 di atas merupakan gambar tool angle untuk menentukkan besar semua sudut yang ada.

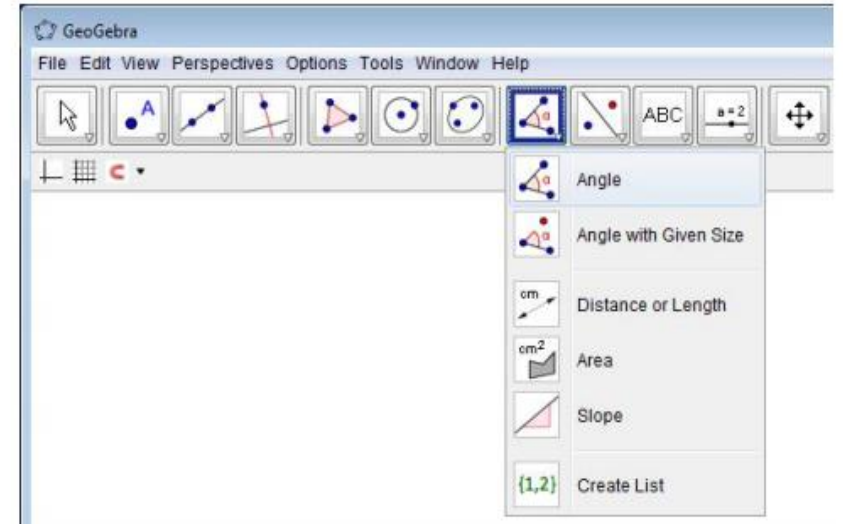

Gambar 4. Tool Angle

Gambar 4 setelah langkah dia atas dilakasnakan maka akan akan menghasilkan gambar seperti di bawah ini. 


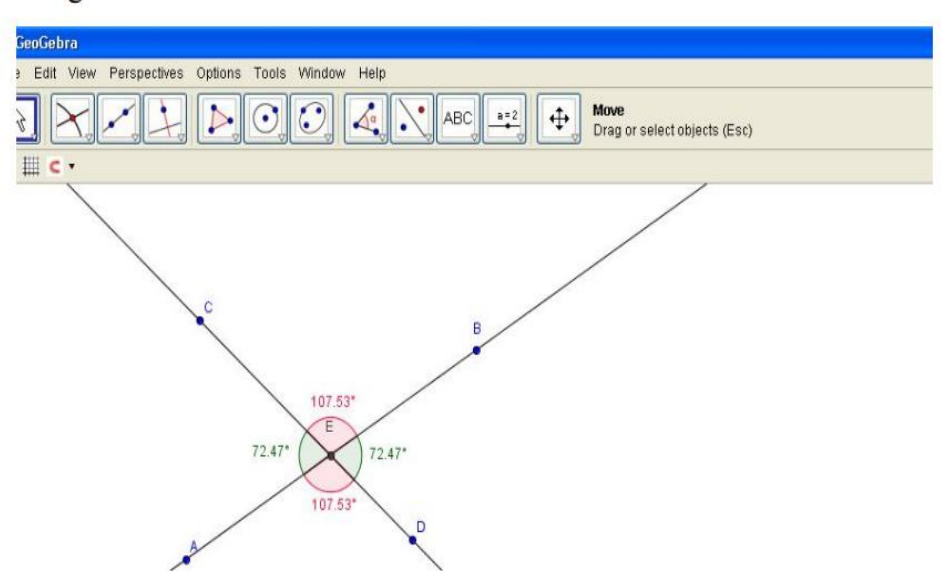

Gambar 5. Sudut bertolak belakang

Dengan cara menggeser atau menggerakan titik a kesembarang arah peserta didik dapat mengukur sudut yang terbentuk. hal ini dilakukan agar siswa dapat menegukur lagi. dengan cara ini peserta dididk dapat menemukan bahwa sudut yang bertolak belakang akan selalu sama besarnya. selain itu melalui kemampuan dapat menggambar grafik suatu persamaan.

\section{Penutup}

Dari hasil penelitian dapat disimpulkan bahwa siswa yang mendapatkan bantuan GeoGebra tanpa GeoGebra dapat belajar matematika, dan kemampuan komunikatifnya dalam matematika lebih baik daripada siswa yang belajar matematika tanpa GeoGebra. Selain itu, hasil penelitian juga menunjukkan bah wa siswa yang mendapatkan pembelajaran matematika aktual tanpa bantuan GeoGebra mengalami peningkatan yang lebih baik dalam keterampilan komunikasi matematisnya dibandingkan siswa yang mendapatkan pembelajaran matematika aktual tanpa bantuan GeoGebra. GeoGebra mampu membatu peserta didik lebih aktif dan sering menaggapi proses pembelajaran yang diterapkan. Maka dapat dikatakan bahwa pemebelajaran yang dilakukan melalui penerpan GeoGebra lebih efektif teritama pada pemebeljaran matematika realistik dibanding dengan pemebeljaran yang dilakukan tanpa bantuan GeoGebra. Sehingga peneliti menghimbau bahwa perlu diadakan penelitian selanjutnya untuk mencari respon positif terhadap peningkatan prestasi siswa terhadap pembeljaran metamatika melalui aplikai GeoGebra.

\section{Ucapan Terima Kasih}

Penelitian ini didanai oleh Kementreian pendidikan dan Kebudayaan Republik Indonesia dalam ham Ini RISTEKBRIN, Untuk penelti mengucapkan banyak terimah kasih atas dana yang telah diberikan kepada peneliti sehingga penelitian ini dapat terselsaikan dengan baik. Begitupula Dinas Pendidikan Kabupaten Bu ru khususnya SMA 1 Buru.

\section{Daftar Pustaka}

Abd. Rahman, F. (2011). "Pengembangan Profesionalitas Guru" dalam Modul A Pengembangan Profesionalisme Guru. Palembang: UNSRI Palembang.

Alan Ralph, Hogan,S.J., Hill. M., et al. (1998). Improving Adolescent Social Competence in Peer Interactions using Correspondence Training. Source. 
Education and Treatment of Children, 21(02), 171-194.

Aw, S. (2011). Komunikasi Interpersonal. Yogyakarta: Graha llmu.

Hares Uki. (2020). Pengembangan Media Pembelajaran Interaktif Menulis Teks Hasil Observasi Bermuatan Konservasi Bagi Peserta Didik Kelas Vii Smp. Jurnal Pendidikan Bahasa Dan Sastra Indonesia, 13(5).

Hohenwarter, M. \& Fuchs, K. (2004). Combination of Dynamic Geometry, Algebra, and Calculus in the Software System Geogebra. Retrieved from www.geogebra.org/publications/pecs

Martin, M. O., Mullis, I. V., \& Foy, P. (2008). TIMSS 2007 International Science report.

NCTM. (2000). Principles and Standards for School Mathematics. The National Council of Teachers of Mathematics, Inc: United States of America.

Permendiknas No. 22 tahun 2006. (2006). No Title.

Prabawanto, S. (2013). menignkatkan kemampuan pemecahan masalah, komunikasi, dan self-effacy matematis mahasiswa melalui pembelajaran dengan pendekatan metacogniteve scaffolding. UPI bandung.

Roehati, E. (2009). Pengembangan Lembar Kerja Siswa (LKS) Mata Pelajaran Sains Kimia untuk SMP. Jakarta.

Sugiyono. (2011). Metode Penelitian Kombinasi (Mix Methods). Bandung: Alfabeta.

Sulastri. (2009). Peningkatan Kemampuan Operasi Hitung Penjumlahan Bilangan Bulat Melalui Media "Red and White Stik" pada Siswa Kelas IV SD Nasima Semarang Tahun pelajaran 2008/2009. Yogyakarta.

Susiati, S., Iye, R., \& S. (2019). Hot Potatoes Multimedia Applications in Evaluation of Indonesian Learning In SMP Students in Buru District. ELS Journal on Interdisciplinary Studies in Humanities, 2(4), 556-570.

Zulkardi. (2002). Developing a Learning Envorinment on Realistic Mathematics Education for Indonesian Students Teachers. University of Twente. Enschede:Printpartners Ipskamp. 